\title{
Unveiling the EU Courts' Internal Decision-Making Process: A Case for Dissenting Opinions?
}

\author{
Josef Azizi
}

(C) ERA 2011

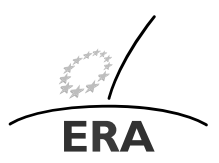

EUROPÄISCHE RECHTSAKADEMIE ACADEMY OF EUROPEAN LAW ACADEMIE DE DROIT EUROPEEN ACCADEMIA DI DIRITTO EUROPEO

ERA 2011

TRIER - TREVES - TREVIRI

\begin{abstract}
The author examines in-depth the arguments speaking pro and contra admitting dissenting (and also concurring) opinions by the judges members of the courts of the European Union. He puts into context the present "opacity" of the EU courts, which decide on the basis of an almost absolute secrecy of their deliberations, which can however be seen as a guarantor of judicial independence insofar as it balances the relatively short term of office and the possible interest of judges in their reappointment. Other aspects considered are the effectiveness of judicial procedure or the internal decision-making process, which might loose speed, persuasiveness and general acceptance if dissenting opinions are admitted. The call for allowing dissenting opinions is perhaps less strongly felt at the level of the ECJ where Advocates General's conclusions complement the judgments.
\end{abstract}

Keywords EU · ECJ · General Court · Dissenting opinions · Judicial independence

\section{Prologue}

Ever since its accession to the European Communities, now the European Union, specifically the United Kingdom has contributed greatly in a very particular manner to promote European integration in that it has been providing the various European organs, bodies or panels with an impressive number of outstanding personalities, thus

All views expressed in this contribution are strictly personal and do not engage anybody but the author. The author would like to thank Hanns Peter Nehl for critically reading through the manuscript.

Prof. Dr. J. Azizi (凶)

Judge at the General Court of the European Union, Luxembourg, Luxembourg

e-mail: rwhiteley@era.int 
significantly and effectively contributing to raising or keeping at a high level the standards of their activities.

One of those eminent personalities is John Toulmin. Besides his manifold other activities, John Toulmin has been for many years the chairman of the ERA Board of Trustees. As a member, and, later on, as vice chairman of that board, I had the sincere human and professional pleasure of working together with him. I finally even had the privilege to thank him in a public laudatio on behalf of the ERA Board of Trustees at the end of the last meeting chaired by him on 12th June 2010, expressing the Board members' gratitude for his extraordinary and most valuable achievements.

The following contribution is meant to voice my personal thanks and wishes, in addition to those already expressed on behalf of the members of the ERA Board of Trustees.

It is the author's sincere hope that John Toulmin, British lawyer, judge and EU law expert may find some interest in the following pages, which deal with questions of the possible application of a specific common law concept to the EU judiciary.

\section{Point of Departure: The Frequent Request for the Publication of Dissenting Opinions in EU Court Proceedings}

Whenever in judicial proceedings a panel of judges is competent to decide on the application and interpretation of a given set of rules, the decision would normally be taken by majority approval, unless unanimity is formally required, and the final judgment would reflect, in its dictum as well as through its reasoning, the sole opinion of a majority of panel members.

It is common ground that, unlike several national judicial systems in- and outside the $\mathrm{EU}^{1}$ and, as distinguished from a number of international courts, ${ }^{2,3}$ the rules governing the EU judiciary do not permit for the disclosure of information on the deliberations and, more specifically, for the publication of so called "dissenting opinions". ${ }^{4}$ Hence, members of a judicial panel of the EU courts ${ }^{5}$ who did not adhere to the majority opinion are not entitled to express publicly their full or partial disagreement with the judgment and explain the reasons for their dissent.

\footnotetext{
${ }^{1}$ See, e.g., Machacek, [22], p. 1; Laffranque [16], p. 163 (at p. 165); Trócsányi/Horváth [36].

${ }^{2}$ See, e.g., as to the very interesting first discussions on the admission of dissenting opinions at international Courts: Witenberg/Desrioux [38], p. 276ff. See also, i.a., Sereni [32], p. 830 (at p. 840fff); Hussain [12]; Peltzer [27].

${ }^{3}$ Specifically as to the European Court of Human Rights, see e.g. the sophisticated analysis by C. Grabenwarter $[8,9]$, p. 16.

${ }^{4}$ The "dissenting opinion" (or "dissent") has to be distinguished from the "concurring opinion", which agrees with the dictum of the panel's decision, but states different reasons. In the practice of the European Court of Human Rights, both dissenting and concurring opinions are called "separate opinions".

${ }^{5}$ I.e.: chambers composed of three or five judges, the Grand chamber (presently: 13 judges, at the ECJ and the GC only) and the Plenary.
} 
However, time and again the claim has been made that the publication of such dissenting opinions be admitted in proceedings before the EU judiciary. ${ }^{6,7}$ A confrontation of the present legal situation with this de lege ferenda proposal brings to light numerous aspects of the question and - not surprisingly - for each of these aspects the appraisal varies depending on the underlying evaluation criteria.

Coming from a Member State whose legal system does not admit the disclosure of dissenting opinions, and after 16 years of experience as an EU Judge, I simply felt like reviewing at least some of these aspects, in order to clear my own mind rather than to convince anybody.

\section{Openness and Secrecy in EU Courts' Proceedings: The Actual Situation}

Pursuant to Article 35 read in conjunction with Article 53(1) of the Statute of the Court of Justice of the European Union, ${ }^{8}$ the deliberations of the European Court of Justice (ECJ) and of the General Court (GC) as well as of the Specialised Court European Civil Service Tribunal (CST), shall be and shall remain secret. The rules of procedure of the ECJ, ${ }^{9}$ of the $\mathrm{GC}^{10}$ and of the $\mathrm{CST}^{11}$ state that "(t)he Court and Chambers shall deliberate in closed session."

In addition to that, when taking their oaths, on assuming their offices, judges, Advocates General ${ }^{12}$ and registrars of EU courts have to declare that they will preserve the secrecy of the deliberations. ${ }^{13}$ Furthermore, the general transparency principle, as laid down in Article 15 TFEU is only of limited application to the EU judiciary: Although the ECJ, the GC and the EU Specialised courts (at present: the CST), which are all parts of the Court of Justice of the European Union as an overall EU institution $^{14}$ are in principle bound to conduct their work as openly as possible, the right of access to their documents shall, in conformity with Article 15(3), subparagraph 4, TFEU only apply when they are exercising their administrative tasks. ${ }^{15}$

\footnotetext{
${ }^{6}$ See, inter alia, Laffranque [17] p. 14-23; Zweigert [39], p. 580 (p. 585f); Riese [29], p. 270 (p. 273 ).

${ }^{7}$ Similar debates on the introduction, enlargement or generalisation of the possibility to publish dissenting opinions have been taking place on the national level of several EU Member States. See, e.g., Mayer [23], p. 30; Machacek [22]; Noll [24], p. 221, and 1993/5, p. 302; Lamprecht [19], p. 117; Rupp [31], p. 531; Faller [6], p. 985; Drion, [5], p. 31; De Savornin Lohman [4], p. 49; Thomassen [34], p. 1; Panizza [25].

${ }^{8}$ Protocol (No 3) on the Statute of the Court of Justice of the European Union, 30 March 2010 (OJ C 83, p. 210).

${ }^{9}$ Article 27(1).

${ }^{10}$ Article 33(1).

${ }^{11}$ Article 27(1).

${ }^{12}$ Since the Advocates General do not take part in the deliberations, it seems unclear in what way they might ever be in a position to breach the secrecy of deliberations.

${ }^{13}$ ECJ Rules of procedure, Article 3(1); GC Rules of procedure, Article 4(1); CST Rules of procedure ... This would also apply to eventual assistance rapporteurs.

${ }^{14}$ See Article 13(1) TEU.

${ }^{15}$ See, in this respect, ECJ judgment of 21 September 2010 in joint cases C-514/07 P, Kingdom of Sweden v Association de la presse internationale ASBL (API) and Commission, C-528/07 P, Association de la presse internationale ASBL (API) v Commission, and C-532/07 P, Commission v Association de la presse internationale ASBL (API), not yet published.
} 
Thus, the obligation to preserve the secrecy of the deliberations, which form a core activity of any court's specific judicial function, is also in line with the prohibition to disclose documents unveiling the internal sphere of judicial decision-making to outsiders. It seems that even on the basis of EU primary law, for some reason information on the way in which the Court's decision was reached is not to be disclosed.

Consequently, the secrecy of deliberations is an obvious exception to the application of the overall transparency principle under Article 15 TFEU.

Whereas a notice on the fact that a case has been lodged with a EU court is published in the OJ, the oral hearings, as a general rule, are open to the public and the Court's final decisions are fully available and sometimes even explained by press releases, any access to information on the EU courts' internal decision-making in specific proceedings is prohibited. More particularly, it is therefore impossible for the parties as well as for the general public, to know the opinions of the different judges members of a judicial board, mostly a chamber, on the specific legal (and factual) questions raised by a particular case, including aspects linked to the methodological approach chosen. Moreover, the full secrecy of deliberations also excludes to reveal the mere number of judges who have adhered to the final judgment and to specify the reasons why they partly or entirely disagree with that judgment.

This opacity of the EU courts' will making process has often been criticised, not least on the basis of the examples (to the contrary) of other international courts and of part or all judiciaries in some of the Member States.

\section{External Aspects: Judicial Legitimacy as Basic Parameter}

\subsection{General Introduction}

\subsubsection{The Point of Reference: Judicial Legitimacy}

In order to evaluate some of the pros and cons concerning the admission of dissenting opinions and the like ${ }^{16}$ before the EU courts, it seems to me that most of those arguments essentially boil down to the following question: Could the approach be seen, on the whole, as being in conformity with an overall concept of "judicial legitimacy"?

Judicial legitimacy would be seen to be best achieved whenever the general objectives and functions of an impartial judiciary as foreseen explicitly or implicitly by the respective constitutional order are met. The characteristics of an independent court and of a fair trial as fundamental features and essential parameters of the judiciary in a modern constitutional legal order ("Rechtsstaat", "État de droit") are, to a wide extent, part of the overall background of this analysis. In this sense, a court's activity must be based on binding laws/statutes, have jurisdiction to decide cases through legally binding and enforceable judgments, court members must be independent and impartial and must not have to justify or report towards any authority or person.

Accordingly, the concept of introducing "dissenting opinions" at EU courts' level on the one hand as well as the concept of "secrecy of deliberations" on the other will have to be examined as to their compatibility with judicial legitimacy.

${ }^{16}$ Including concurring opinions or a bare statement of dissent. 


\subsubsection{Possible Objectives and Functions of Courts and Courts' Proceedings}

In the first place, the basic functions of a judiciary could be seen either in a more static or in a more dynamic way. Seen in a more static way, the judiciary would have, above all, a stabilising function. Seen in a more dynamic way, the court's function might help the legal order evolve and find better answers to old problems and adequate upto-date answers to new problems. This may also imply a specific propensity to an intensive use of all legal remedies available.

\subsection{The Courts' Function as Providers of Legal Stability}

\subsubsection{The Basic Concept}

It could be stated that a court should grant legal protection by interpreting and thus clarifying the rules fixed by the legislator and applying them to a concrete case, in such a way as to render the law not only - where necessary - more transparent, but above all effective between the parties through a legally binding judicial decision.

In this perspective, the court's activity tends to stabilise the legal system, in the first place, by ensuring or re-establishing peace and legal certainty in a specific case. But well beyond that, under ideal conditions, by doing so, the court's activity would tend to legitimise the legal system as a whole in manifold ways: It would lead to pacifying the parties of the case, not only as to the particular subject of pending litigation decided by the court, but also with respect to their future relationship as to the basic legal and factual questions clarified by the judgment. Moreover, in parallel, the judgment might also have a future clarifying effect on other persons liable to face the same type of legal problems. In this sense, a judgment would, beyond the boundaries of the case actually settled, have a pacifying and preventive effect also for the future, thus reducing the likelihood and frequency of future litigation.

However, this ideal model of a court stabilising the legal system can only work if several conditions are satisfied. Indeed, in order to contribute to this stabilising overall function, courts would have at least to meet the following conditions: Foremost, they must be seen to have a high degree of legitimacy, not only from an organisational point of view but also in respect of their efficiency at work.

\subsubsection{Legitimacy Through Independence}

\subsubsection{Conceptual Elements of Judicial Independence The organisational legiti-} macy of a court is essentially based on the full independence of its judges in the exercise of their office. The central idea underlying the fundamental requirement of judicial independence is that the members of a judicial body should not be exposed to any instructions or external pressure possibly designed to influence their decisionmaking and thus to hamper their impartiality. ${ }^{17}$ From a merely organisational point

\footnotetext{
${ }^{17}$ Concerning the close connection between judicial independence and impartiality, see, e.g., Grabenwarter [9], p. 300, and the case law cited. As to these two essential characteristics see also, e.g., Frowein/Peukert [7], p. 221-231.
} 
of view, the independence of judges is ensured mainly by the following three criteria ("guarantees of judicial independence"): Judges must be under nobody's directions, instructions or orders (freedom from instruction), they must not be transferred or removed against their will to another post (freedom from displacement, freedom from transfer) and they must not be dismissed or recalled before the end of their tenure of office (freedom from dismissal). ${ }^{18}$

Now, as the ECHR has recognised under Article 6 of the European Convention of Human Rights, ${ }^{19}$ in order to meet the criteria of independence, what matters above all is already the mere external appearance ${ }^{20}$ : If, as seen from the outside, there are elements liable to cast a shadow of doubt on the appearance of full independence of the members of a judicial panel, that would be sufficient in itself to infer the lack of independence of such a judicial body.

\subsubsection{Specific Tensions Between the Concepts of "Independence" and "Trans- parency" in the EU Courts}

4.2.2.2.1 Primary Factors of Independence This having been said, if one takes a look a the basic organisational position of EU judges, there can be no doubt that they are free from any instructions and that in principle they cannot be transferred to another post or recalled from their functions without their consent.

4.2.2.2.2 Factors Potentially Undermining Independence However, what may possibly give rise to some doubts, are the following elements:

On the one hand, the EU judges' term of office of only six years is relatively short, lying just above the five years period normally recognised by the ECHR as satisfying the criteria of minimum term of office ${ }^{21}$ assuring the necessary appearance of independence. Sometimes, their first appointment confers even only a much shorter term of office, in order to fit with the rhythm of partial replacement or renewing periods foreseen under Articles 253(2) and 254(3) TFEU. ${ }^{22}$

On the other hand, EU judges are appointed by common accord of the Member States $^{23}$ or by unanimous decision of the Council ${ }^{24}$ and they may be reappointed. ${ }^{25}$

\footnotetext{
${ }^{18}$ See, e.g., Papier [26], p. 1089.

${ }^{19}$ In view of the surprisingly broad definition of "Civil rights" given by the European Court of Human Rights (see, e.g., Judgment of 23.10.1985 in case Benthem, A97 = EuGRZ 1986, 299), I would not doubt that Article 6 ECHR would be applicable to a large portion of EU Court proceedings. See also the examples of case law given Grabenwarter [9], p. $284 \mathrm{f}$. Even the more so, by virtue of Article 52(3) of the Charter of Fundamental Rights of the European Union, Article 47 of the Charter, which has a broader scope than Article 6 of the Convention, would apply to all EU Court proceedings.

${ }^{20}$ See, e.g., case Sramek/Austria, A 84(1984) = EuGRZ 1985, p. 336; case Belilos, A 132(1988)=EuGRZ 1989, 21, Z. 67.

${ }^{21}$ See Grabenwarter [9], p. 297 f.

${ }^{22}$ E.g., after the accession of Austria, Finland and Sweden to the European Union, the first mandate of the judge from Sweden at the Court of First Instance (CFI) lasted only about 7 months.

${ }^{23}$ ECJ and GC: see Article 19(2), subparagraphs 3 and 4.

${ }^{24}$ European Union Civil Service Tribunal: see Article 257(4), last sentence, TFEU; see Article 2(2) of Annex I to the Statute of the Court of Justice of the EU.

${ }^{25}$ See also Article 254(2) TFEU: "Retiring members shall be eligible for reappointment".
} 
It is true that the Treaties require that judges be chosen from persons whose independence is beyond doubts and the appointment procedure includes the consultation of a special committee ${ }^{26}$ to ensure the candidates' suitability to perform the duties of a judge at the EU court in question. Yet, the very fact that judges may be reappointed could be seen as putting at risk their independence: It could be submitted that judges would be more likely to be reappointed (or at least proposed for reappointment) if the judgments in which they participated were favourable to the Member States' interests, and even, more specifically, to the interest of their Member State of origin, which has traditionally the prerogative of proposal. ${ }^{27}$

4.2.2.2.3 Prima Facie Appreciation of the Secrecy of Deliberations Seen in this light, if there is no publicly available information on the judges' position and contribution in the internal decision-making as to the substance of a judicial decision, the ensuing limitation of transparency could even be seen as preventing a possible appearance of an only limited independence of judges ${ }^{28}$ : Indeed, the more the personal behaviour of a judge within the deliberation is kept secret, the less its possible perception and assessment by the outside world can have an influence on his or her future career and, consequently, bias his or her vote in an anticipative manner. This is true not only of a situation where the judges may be reappointed, but also as a matter of fact of any situation where the end of the term of office of a judge would not coincide with the actual end of his or her professional career: Every time a judge in office knows he or she will have to find himself or herself a future professional career, it cannot be ruled out that the perception of his or her judicial behaviour by a potential employer might have an influence on that behaviour. ${ }^{29}$

Seen from this angle, the obligation to keep the secrecy of deliberations is simply an appropriate means to guarantee judicial independence, ${ }^{30}$ in particular, it compensates for any impairment of independence possibly caused by the but limited term of office of judges, as well if they may be reappointed as if they are allowed to take up other professional functions after the end of their judicial term of office. Otherwise, under these circumstances, any possibility to disclose the personal voting behaviour of a judge may turn into a means of constraint or pressure to justify publicly the personal reasons for agreeing or disagreeing with the judicial decision.

\footnotetext{
${ }^{26}$ ECJ and GC: See Article 19(2), subparagraph 3, in connection with Articles 253(1) TFEU and 254(2) TFEU as well as Article 255 TFEU. CST: See Article 257(4) TFEU; see also Article 3(3) and (4) of Annex I to the Statute.

${ }^{27}$ It is therefore, in the first place, the professional status and positioning of the judge which is decisive for an eventual viability or inappropriateness of dissenting opinions. Conversely, on the basis of the quite specific and different position of "common law" judges, Rupp [31], p. 535f, would see the merits of dissenting opinions.

${ }^{28}$ See, in this sense, already Klinke [14], p. 62.

${ }^{29}$ Accordingly, under rules providing the possibility of dissenting opinions and even if the term of office lasts for a rather long period (e.g. 12 years for the German Bundesverfassungsgericht), it would seem adequate to appoint only judges sufficiently close to the age of retirement or coming from the judiciary (maybe the possible return to a merely academic career would also be a perspective not putting at risk the appearance of independence).

${ }^{30}$ Tizzano [35].
} 
4.2.2.2.4 Verification Test: Member States' (and Other Actors') Actual Role in Court Proceedings A closer glance at the current practice of the ECJ and the GC confirms this statement: As a matter of fact, in view of the role of Member States for the reappointment of judges in the context of EU law, the appearance of independence of the Court may be impeded in more than one respect by the admission of dissenting opinions:

First of all, it should be recalled that judges at the EU courts, once they are appointed, are to be seen exclusively as "European" judges and not as representing their Member State of origin. The fact that a judge stems from a particular Member State has no significance for his or her sitting in a particular case involving that Member State: His or her presence in such a case is neither requested ${ }^{31}$ nor excluded. However, a judge would normally not be appointed reporting judge in a case concerning his or her Member State of origin. The sole reason for the obligation to appoint one (or at least one) judge per Member State is due to the need to have all the legal traditions of all Member States present at the EU courts' level. ${ }^{32}$

Yet, the disclosure of the concrete attitude of a judge in a case involving his or her Member State of origin could well destabilise this sensible adequate distance ${ }^{33}$ and raise the above mentioned doubts or suspicions as to the judge's full independence and impartiality. Categories of cases involving States as main parties are above all infringement proceedings against Member States ${ }^{34}$ and direct actions brought by Member States. ${ }^{35}$ Member States would also be involved in preliminary ruling proceedings ${ }^{36}$ as well as in any other proceedings in which they apply to intervene. ${ }^{37}$

In all these types of proceedings, the possibility of making known the position of a judge, member of a judicial board, could put him or her under pressure to change his or her attitude in order to be in line with his or her Member State or with the public opinion prevailing in his or her Member State. ${ }^{38}$ In this respect, the relevant question is not so much as to whether or not a judge would be strong enough to resist such potential pressures which might possibly lead him or her to anticipate the desired attitude; relevant is only that the mere taint of the external appearance or even likelihood to meet such expectations could not be ruled out.

\footnotetext{
${ }^{31}$ By contrast, e.g., to the proceedings before the European Court of Human Rights.

${ }^{32}$ The ideal of reflecting the plurality of legal traditions also explains why at the GC, the chambers of three judges are composed in such a way as to reflect genuinely different legal traditions in order to prevent any one-sided distortion in legal thinking. For example, it is systematically avoided, as far as possible, that the judge from Ireland and the judge from the UK, or the judge from Belgium and the judge from France, or judges from two Nordic Member States, or the judge from Austria and the judge from Germany, or the judge from Belgium and the judge from the Netherlands would be members of the same chamber of three.

${ }^{33}$ In this same sense: Knaub [15], p. 272 (287), whose fear concerning an excessive length of the publication of dissenting opinions seems less convincing. Hakenberg/Stix-Hackl [10], p. 31. See also e.g. Brown/Kennedy [40], p. 319.

${ }^{34}$ ECJ, Articles 258, 259 and 260 TFEU.

${ }^{35}$ Mainly GC, Articles 263, 265, 340(2) TFEU.

${ }^{36}$ ECJ: Article 267 TFEU.

${ }^{37} \mathrm{Cf}$. Article 40 of the Statute.

${ }^{38}$ Storme/Maresceau [33], p. 28, suggested that at their stage of the European integration process, the "Anglo-Saxon" practice of the "dissenting opinion" would not be fit for the ECJ and would not be desirable, in order to avoid the forming of majorities on a merely nationalistic basis.
} 
Similarly, it cannot be ruled out either that in cases pending before the ECJ and the $\mathrm{GC},{ }^{39}$ economical and political actors or pressure groups might have a strong interest in influencing the outcome of the proceedings by putting judges who have to envisage future professional alternatives under a pressure to meet their expectations.

Nonetheless, there is one situation in which, by definition, the "deliberations" would never be a secret to anyone: Whenever the relevant laws foresee that a judicial decision be taken by a single judge, the final decision is fully attributable to that judge and necessarily reflects his or her thinking, exposing his or her personal valuing and intentions. Within the EU judiciary, the particular situations where a single judge takes judicial decisions are mainly limited to the following cases: on the one hand, in proceedings on interim measures ("summary procedure"), for reasons of urgency and time constraint, reserved to the presidents of the respective EU Court or a single judge designated for that very purpose by the plenary. ${ }^{40}$ On the other hand, in proceedings before the GC or the CST, in certain types of less complicated cases, the competent chamber may assign a case to a single judge. ${ }^{41}$

But even taking into consideration these very specific exceptions to the principle of secrecy of deliberation, ${ }^{42}$ it must be stated that, for the overwhelming majority of cases decided by the EU courts, the decision is taken by a judicial board where the obligation of secrecy fully applies. Consequently, reasons justifying the secrecy of deliberations and thus excluding dissenting opinions would apply to by far the largest number of EU Court proceedings. They would prevail for as long as the but limited legal term of office confronts judges with the need for future professional perspectives.

\subsubsection{Legitimacy Through Effectiveness of Legal Protection}

4.2.3.1 General Observation Apart from independence and professional qualification in the sense of organisational aspects of legitimacy - it would seem to me that the effectiveness of legal protection is yet another pillar of judicial legitimacy. Indeed, the more a court is efficient, on the short term as well as on the long term, in fulfilling its pacifying function, the more it will gain legitimacy in the eyes of the parties as well as of the general public.

\footnotetext{
${ }^{39}$ E.g., as to actions for annulment or preliminary rulings in cases dealing with competition law, State aids law, antidumping law, the admission of dangerous substances, environmental questions, consumer protection, and many others, as well as contractual arbitration cases under Article 272 TFEU.

${ }^{40}$ See Article 39 of the Statute in connection with Articles 278 and 279 TFEU; see also e.g.: Title 3, Chap. 1 of the Rules of Procedure of the GC: The Presidents of the EU Courts or the Presidents of chamber have also the competence to take a number of procedural decisions.

${ }^{41}$ See Article 14(2), Rules of Procedure, Article 14, Rules of Procedure of the CST.

${ }^{42}$ These exceptions could be justified, as to the role of the Court's Presidents for interim measures, with the fact that, whoever applies to be elected for the function of President or for his replacement is aware of this specific visibility of the exercise of his responsibilities upon specific appointment (election) by the plenary. As to single judge functions of "simple judges", they are limited to cases without particular legal or factual bearing.
} 
In this context, I tend to distinguish between procedural effectiveness, substantial effectiveness and completeness of legal protection. ${ }^{43}$

\subsubsection{Procedural Effectiveness by Way of Quickness and Transparency of Judicial Proceedings}

4.2.3.2.1 Introductory Statement As to the realisation of procedural effectiveness serving a court's legitimacy, two essential parameters should be kept in mind: on the one hand the quickness and on the other hand, the transparency of judicial proceedings. Indeed, the swiftness of judicial proceedings is a major factor of their effectiveness, ${ }^{44}$ in the same way as the already mentioned transparency of judicial proceedings: In principle, the more transparent a procedure is perceived to be, the more the parties concerned would feel confident not to be subject to unfathomable circumstances. $^{45}$

4.2.3.2.2 Quickness of Proceedings Versus Dissenting Opinions? To confront the question of the utility of dissenting opinions with the required quickness of proceedings, the following should be mentioned: Some authors object to the admissibility of dissenting opinions because the possibility to prepare and publish dissenting opinions would slow down judicial proceedings which would therefore hamper the procedural effectiveness of legal protection. ${ }^{46}$ To my opinion, this argument is not necessarily correct: It would suffice to organise in due time mutually coordinated information and action between the majority of the judicial board and the dissenter, in order to allow the dissenter to prepare his or her opinion without much delay.

4.2.3.2.3 Once More: the Tension Between Transparency of EU Court's Proceedings and the Secrecy of Deliberation As to the transparency aspect, it would seem that the transparency of court proceedings contributes to the acceptance of the ensuing judgment and thus to the effectiveness of the court's activities by helping to realise effective pacification and, consequently, to increase its legitimacy. In this respect, at the level of EU courts, the parties' right of access to the file and their right to be heard guarantee a high degree of transparency of the proceedings, not to speak of the public notice on registered applications ${ }^{47}$ as well as the public access, in principle, to all hearings ${ }^{48}$ and judgments.

Nonetheless, as already explained, within EU courts proceedings the principle of transparency is indeed limited by the secrecy of deliberations. Accordingly, even if this restriction on the principle of transparency seems justified in order to preserve full

\footnotetext{
${ }^{43}$ The completeness of legal protection concerns the question to what extent legal remedies available in EU law cover all possible claims in connection with any illegalities committed under EU law. As this factor does not seem to be relevant in the present context of dissenting opinions, it shall not be further examined.

${ }^{44}$ As expressed by the sayings "Bis dat qui cito dat!" or even "Justice delayed is justice denied."

${ }^{45}$ As a matter of fact, the complete contrary of a proceeding showing the required or necessary degree of transparency would be various medieval types of Court proceedings like Vehmic courts or historical inquisitorial proceedings, where parts of the file were hidden from the person put on trial.

${ }^{46}$ Drion [5], at p. 38.

${ }^{47}$ See, e.g., Article 24(6) of the Rules of Procedure of the GC.

${ }^{48}$ See Article 31 of the Statute.
} 
judicial independence of EU courts (see above, Sects. 4.2.2.2.3), the simple fact of keeping the EU courts' deliberations secret is likely to reduce the courts' credibility and hence to hamper the legitimating effectiveness of its proceedings, in so far as it entails a reduction of transparency.

4.2.3.2.4 The Necessary Counterbalance: The Statement of Reasons as Central Piece of Judicial Transparency and Overall Judicial Legitimacy The question therefore still remains whether the EU legal system provides a remedy against this specific impairment of procedural legitimacy. Yet, this seeming partial lack of transparency may and must be compensated by a clearly and fully reasoned judgment. As a matter of fact, the obligation for the EU courts to provide adequate reasoning must lead to the adoption of judgments whose reasoning would not only be clear and free from any logic inconsistencies, but would also be sufficiently detailed to answer all questions relevant for the understanding of the decision's dictum.

Indeed, an adequately reasoned judgment should fully stand for itself, without it being necessary to disclose the number or name of judges who partly or entirely disagreed with the final judgment or to specify their particular positions within the overall group dynamic process of the deliberations.

Correspondingly, the self-explaining quality of the judgments' reasoning must be the essential counterweight to the absence of transparency of the court's deliberations. In such a way, judicial legitimacy through procedural effectiveness can be secured even in the particular context of transparency for judicial proceedings without suffering any impairment by the secrecy of deliberations.

Indeed, as a matter of fact, a convincing and sufficiently exhaustive reasoning contributes decisively to any judgment's acceptability and thus is a core element safeguarding substantial effectiveness of judicial proceedings, helping to clarify and stabilise in a durable (in an on-lasting) way the questions in dispute between the litigating parties on the one hand and preventing, more generally, the future emergence of further litigation in similar cases on the other.

After all, along these lines, such a convincing and sufficiently clear reasoning in a judgment tends to enhance legal security as to the application and interpretation of a legal rule in the presence of a certain type of facts, or a combination of facts, by deepening the perception of foreseeability and giving rise to an expectation of stability as to the legal application and interpretation of the relevant legal rules.

As a matter of fact, some judgments of the ECJ have been criticised for containing only a very brief reasoning. On the contrary, judgments of the GC are often criticised for being too lengthy.

How have these criticisms to be seen in the light of the debate on introducing dissenting opinions? It appears to me that the attempt of a first instance court to provide the parties with a sufficiently complete reasoning, especially in view of their right of appeal, lessens the possible arguments for a disclosure of dissenting opinions. On the other hand, as for the ECJ in its role as a constitutional or last instance court, there is, at least in important cases, the practice to associate an Advocate General to the proceedings, whose opinion could be seen as complementary informational background to the statement of reasons in the ECJ judgment. 


\subsection{4 “Dissenting Opinions” as Point of Divergence (Separation)/Intersection Between Legal Stability and Legal Dynamism}

If we can accept the basic premise that a judgment's statement of reasons constitutes the centre piece ideally enhancing its substantial legal correctness as well as its legitimacy and acceptance, then the following next question arises: Would the publication of dissenting opinions weaken or strengthen the judgment's reasoning?

Yet, in this respect, it would seem that, by eliminating the secrecy of deliberations, and, more specifically, by rendering public the opinions and arguments of members of the judicial panel who entirely or partially disagree with the judgment, the solution found and argued in the judgment's reasoning could as well be weakened as strengthened.

Indeed, if one considers the abovementioned concept of legal stabilisation (see point Sect. 4.2.3.2 above) as the one and only determining model of judicial functions, then any factor disturbing (impeding) this stabilising function would have to be avoided. From the outset, it could be seen as weakened already in as much as the very fact of a lack of unanimity in the court on a disputed question would deprive the judgment of the appearance of being the only seriously conceivable solution and way of argumentation.

This effect of rendering the judgment at first sight more optional and less compelling would be further increased if the number of dissenting judges in proportion to the majority of judges supporting the judgment is made known to the parties and to the public, even if the names of the respective judges are not disclosed. Indeed, if it shows that the judicial decision had been adopted only by a bare majority, the legal security function of the judgment might be diminished ${ }^{49}$ and even seriously hampered and impaired: For actually, instead of being reassuring as to the exclusion of any other solution, such information on the panel's divergent points of view could have a "meteorological" side effect: The German phrase, "on the high seas and in court we are in God's hands", 50 makes it clear that, from the outset, there is an element of uncertainty as to the outcome of many judicial litigations. The higher the degree of apparent uncertainty, the more likely it is that the parties, like for the weather, would try their best to make a "meteorological forecast" on the basis of any available information. As soon as information on the fact of divergences amongst the judges and on their numerical proportion is rendered available, parties whose claim would have been favoured by a minority opinion rather than by the actual judgment are more likely to seek its annulment and overruling by lodging an appeal. In the same way, in future similar factual and legal circumstances, the persons involved are more likely to start a new trial in the hope the once minority vote might now override the former majority opinion.

Paradoxically, seen from this point of view, it would seem that the additional amount of information gathered through eliminating the secrecy of deliberations

\footnotetext{
${ }^{49}$ E.g.: After the German Bundesverfassungsgericht had rendered its decision in the first "Kruzifix" case (BVerfG, Order of 15 May 1995, 1 BvR 1087/91 = NJW 1995, p. 2477-2483), popular media vigorously called into question the value of a judgment adopted "only by a 5:3 majority".

${ }^{50}$ „Auf hoher See und vor Gericht sind wir in Gottes Hand.“
} 
somewhat tends to reduce that appearance of predictability of judicial behaviour, and therefore contributes to legal uncertainty and thus to a reduction of the aforementioned stability/pacifying function of the judiciary. As a matter of fact, this element of increased uncertainty will tend to trigger an increased interest on the part of the lawyers not only in predicting the future case law (maybe even through making conjectures according to a panel's personal composition) but also in exercising maximum influence on future case law, aiming to overturn the earlier case law on the basis of the additional information given by the dissenting opinion.

It is, above all, a question of legal and judicial policy, whether one would find such inherent dynamics for the evolution preferable to a view which would see the court's role in the first place as a mainly stabilising factor.

In my view, the refinement of judicial argumentation and, ultimately, of case law as a result of such a continuous discussion and confrontation with alternative or additional points of view would undoubtedly have merits in comparison with a simplistic and mechanistic standardised mere repetition of former case law formulas without tinging the Court's arguments in order to fit the specificities of the case ${ }^{51}$ or to eliminate possible inconsistencies of earlier case law.

\subsection{External Criticism: An Indispensable Accompanying Requisite of Independent Justice}

\subsubsection{General Statement}

In an open democratic society, every use of power must be open to critical analysis. This is also true for judicial decisions with respect to the rule of law. Accordingly, the possibility of external criticism to judgments is, as a matter of principle, an essential prerequisite for a free legal system under the rule of law. Thus, it seems primordial that judgments be exposed to intensive analysis and possible criticism.

Here again, the statement of reasons of a judgment, in connection with its dictum, has to be solid enough in its completeness as to the relevant points of fact and law and in its internal logical coherence, in order to withstand arguments of immanent and - possibly - transcendent criticism. Immanent criticism would be of a merely legal nature and refer to exclusively legal and (methodo-)logical premises, whereas transcendent criticism might refer to extralegal parameters. It has to be stated, though, that since legal considerations involve necessarily value judgments, which is also the case for political considerations, the line between legal criticisms on the one hand and merely political criticisms on the other hand is difficult to be drawn and depends mainly on the definition of the written or unwritten legal frame.

All in all, if it is justified, criticism of judgments not only from the parties and the general public but more specifically from the legal academic world would be

\footnotetext{
${ }^{51}$ As I see it, the ascertainment of the specific features of a judicial case and its positioning with regard to earlier case law could be characterised in a manner somewhat similar to the basic modus operandi chosen by Linné, more than 200 years ago, for the constitution of the botanical system: "genus proximum et differentia specifica", in the sense of: "Find the closest case and look for the distinguishing difference" (as well to the facts as to the law). Such a methodological approach must always be open to refinement by paying regard to possibly relevant nuances as to the facts, the legal frame and their respective interplay.
} 
wholly legitimate and can contribute significantly, by way of a so to speak cybernetic feedback process, to the improvement of the case law by helping to pinpoint and eliminate possible errors. But for this purpose, it is not a prerequisite to have an insight into the internal deliberation process.

Therefore, even if the disclosure of dissenting opinions may undoubtedly increase the possibility to bring to light potential weak points and shortcomings of a judgment, they would have no particular added value in comparison to a well understood full and systematic criticism by legal professionals and legal academics.

\subsubsection{Academic Requests for the Disclosure of Dissenting Opinions}

From time to time, researchers from various academic areas express their wish for a disclosure of dissenting opinions.

In this respect, from a merely legal sociological or historical point of view, it would seem comprehensible that social scientists have an interest in the disclosure of dissenting opinions: This would allow them, for their empirical understanding, to have a better insight into the internal group dynamical decision-making process as well as to verify hypotheses on possible paralegal factors of a social, economic or psychological nature possibly underlying that process. But the question remains whether this mere scientific interest, though in itself legitimate, would have to be taken as a sufficient reason for modifying rules governing the functioning of a judiciary.

However, still from an academic point of view, it would seem much less understandable if academic lawyers claimed for the disclosure of dissenting opinions, merely to know, in the interest of academic completeness, what other arguments and approaches could have been chosen. Obviously, by invoking these grounds, a legal academic would give himself or herself away and betray his or her incompetence: Indeed, in his or her analysis of a specific judgment, any true legal academic deserving this qualification should be perfectly capable to fancy and find out by him- or herself, and without the help of dissenting opinions, what alternative approaches would have been possible. Conversely, the only information exceeding what the outside legal academic world must be able to find out by itself as to the qualities or deficiencies of a judgment would be the disclosure of the standpoint and identity of individual persons, namely of each of the judges members of a judicial panel in the exercise of their office. However, this information would not have the least legal relevance. Consequently, not losing from sight the essential element of judicial legitimacy, this merely academic request would not seem convincing to alter the judicial practice as to the disclosure or secrecy of dissenting opinions.

\subsubsection{Democratic Legitimacy as Crowbar for EU Courts' Full Transparency?}

Without doubt, the principle of transparency, in an open democracy, is an essential factor not only to prevent and combat any abuse of power but also to give the electors information on the way the trust they put in the elected persons is being used. Accordingly, in an open democracy, the electors would have a basic right to full transparency as to political decision-making. Therefore, it is only legitimate that minority members of parliamentary committees should have the right to present their own dissenting opinion in parallel to the committee's majority proposal. 
Democratically elected organs must be accountable of their activities to the general public they represent. But this is not the case for EU judges: They are appointed by the Member States (or the Council) inter alia for their capacity to be independent. As for their professional work, judges of EU courts are not accountable to the general public, but to their own independent conscience. Therefore, the request for the disclosure of dissenting opinions at EU courts for the sake of democratic transparency would be besides the point and thus irrelevant and inoperative.

\subsection{Advocates General's Hybrid Role: Forestalling Dissenting Opinions?}

In the course of ECJ proceedings, the Court may have recourse to the cooperation of an Advocate General in cases raising new points of law and therefore "requiring his involvement". 52 Prior to the deliberations (or at least before their close) the Advocate General delivers reasoned submissions to the Court. These opinions are neither legally binding on the Court nor part of the internal deliberations. Nonetheless, in his role as a privileged participant to the proceedings, the Advocate General is in a position, towards the parties, to proceed to a full ascertainment of the relevant points of fact or of law. This submission, which is delivered after the hearing, gives the Court (and more specifically the reporting judge) the opportunity to reflect upon an independent opinion. Thus, the submission of the Advocate General certainly has not the character of a separate opinion of a member of the judicial chamber, but - since it is mostly very profound and well reflected - it still helps the parties and third persons to put-by contrast—-some light upon possible unclear passages of the later judgment. ${ }^{53}$

\section{Internal Aspects: The Proper Decision-Making}

\section{1 "Single Judge” Versus "Organe Collégial”: Legal Environment Through Historical Concepts?}

Historically speaking, it would seem that the concept (idea) that a judicial board delivers one single judgment reflecting the opinion of the majority and without the possibility for the expression of dissenting opinions is linked to the continental legal notion of a "collegiate body" ("Kollegialorgan", "organe collégial"), designating an organ/a body consisting of a plurality of persons. If the internal rules for decisionmaking of such a body are met, the decision is deemed to have been taken by the organ as a whole. The publication of dissenting opinions would, under this legal aspect, seem superfluous and even contrary to the fiction of legal unity of that organ. More particularly, it might often be seen as a depreciation or even detraction of the authority of the board's decision.

\footnotetext{
${ }^{52}$ See Article 252(2) TFEU in conjunction with Article 20(4) of the Statute.

${ }^{53}$ For Lagrange [18], p. 5 (at p. 14f), the Advocates General are the compensation of the absence of dissenting opinions at the ECJ; of the same opinion: louis/Vandersanden/Waelbroek/Waelbroek [21] La Cour de justice - Les actes des institutions, Commentaire Megret, Le droit de la CEE, 2ème edition, Etudes européennes, Bruxelles (1993), p. 34. See also Brown/Kennedy [40].
} 
On the contrary, it would seem that, historically speaking, the idea of admitting the publication of dissenting opinions is derived from the original traditional common law concept of the "single judge" 54 : Even in a judicial body consisting of more than one member, each of the members would still consider him- or herself as a fully autonomous judge with the right to publish his or her opinion as if it were rendered by a single judge, ${ }^{55}$ not withstanding the fact that only the majority's decision would have the legally binding effect of a judgment. ${ }^{56}$

Seen in this light, it would seem that the concept of published dissenting opinions is based on a maybe stronger individual self-understanding of the different members of a judicial board, accompanied by a corresponding external visibility. To put it bluntly, the reproach could be made that in earlier days, when decision-makers wanted to get rid of somebody under the comfortable shade of anonymity or impersonal shared responsibility, they used collective mechanisms like stoning or ostracism, whereas nowadays, they may use judicial panels whose deliberations are kept secret. ${ }^{57}$

In this regard, the point at issue is nothing less than the role concept of the individual judge member of a judicial panel.

On the one hand, it is obvious that any judge worthy of his or her office should have the intellectual and moral capacity to develop his or her own thinking and to publicly stand up for it, as clearly favoured by the "common law model". On the other hand, the "continental model", under its external appearance of a somewhat "depersonalised" and uniform body, ${ }^{58}$ may give rise to less individualism. It however

\footnotetext{
${ }^{54}$ Nevertheless, there seem to have been similar tendencies also in certain German courts, in the course of the 19th century: see, e.g., Heyde [11], p. 204-210; see also Rupp [31], who, besides giving an interesting account on several factors which have favoured the development of dissenting opinions in the "common law" systems (at pp. 532 and 535f), mentions the practice of dissenting opinions in Switzerland and (besides for the Bundesverfassungsgericht) - mostly regionally and historically - before some German courts. See for another equally regional experience Arndt [1].

${ }^{55}$ This seems to be particularly the case for the Law Lords of the United Kingdom, inasmuch as they seem to give each an opinion of their own, without any aggregated judgment being foreseen.

${ }^{56}$ See, e.g., the brief narration given by Noll [24], p. 221 with further references; Jackson [13]), p. 17; it seems, by the way, that the U.S. judicial review system was initially influenced by the British Privy Council's practice [Beth [3], p. 22, at p. 33], even if the right of minority members of the Judicial Committee of the Privy Council to present a dissenting opinion was only conceded in 1966 (Judicial Committee Dissenting Order in Council, 4.3.1966): see Philipp [28], p. 134.

${ }^{57}$ Thus, the "common law" concept would maybe favour the individual courage to follow one's conscience and convictions by virtue of an upright demeanour, which might correspond to protestant tradition. But there is the risk that this outspokenness could perhaps be mistaken, by the other members of the panel, for an expression of conceit and presumption.

${ }^{58}$ Following Bustamante, "la conscience individuelle ne pourra se réfugier dans la résolution anonyme d'un groupe indéterminé" (Lemonon [20], p. 225, as quoted by Witenberg/Desrioux [38], p. 277. See also Arndt [1], at p. 141. As to the question of "anonymity" v. "transparency" in the practice of the German Bundesverfassungsgericht, see Lamprecht [41], p. $25 \mathrm{ff}$.
} 
seems to favour modesty by imposing personal self-restraint ${ }^{59}$ and to give a certain incentive towards the finding of a common understanding amongst the judges. ${ }^{60}$

Either concept has undoubtedly its proper merits and will have to be seen in its specific cultural and social context. How about the cultural and social context of the EU Courts?

\subsection{Internal Decision-Making Features of EU Courts: A Casting Mould for Diversities}

\subsubsection{EU Law as a Basis, Means and Object of the EU Judiciary}

The system of EU law forms an autonomous legal order of its own, different as well from national law as from public international law. ${ }^{61}$ This circumstance as well as the specific tasks and competences of EU courts distinguish them and their activities not only from national courts but also from other international courts. On the basis of the relevant EU rules, EU judgments are binding means for the uniform interpretation of these rules and for their application to specific cases throughout the European Union at various levels, hereby possibly confirming or modifying a legal situation.

The compelling direct effect of EU judgments and their guiding and unifying character as well for the EU level as for the national level in the ambit of EU law gives the EU courts' activities their own special dimension and importance.

This background of coercive but manifold legal functions of the EU courts should be kept in mind for a better comprehension of the current practice of their internal decision-making, as explained below.

\subsubsection{The Current Internal Practice}

In order to understand the internal functioning of the EU courts' proper mode of decision-making, it is essential, besides their specific legal functions (see above, point 1), to recall the heterogeneous and manifold geographical, professional and, above all, legal tradition background of the members of their judicial boards (see e.g. footnote 32 above), ${ }^{62}$ and the fact that, generally, they identify with their role as European judges and are keen to achieve, in each particular case, a result best possibly suiting (apt) for the consolidation of the EU legal order and the legal protection of individuals.

\footnotetext{
${ }^{59}$ It is not without reason that even Rupp [31], p. 549, albeit advocating the general admission of dissenting opinions in German courts, insists on the paramount necessity of self-restraint for the use of dissenting opinions.

${ }^{60}$ As to the "opposition des pratiques continentale et anglo-saxonne" in this respect, see already J.C. Witenberg/J. Desbriou [38], p. 277). Following these authors, who give a detailed description of the first cases of dissenting opinions at international level, the recognition of the concept of "dissenting opinions" in the practice of international jurisdictions is mainly due to "Anglo-Saxon" influence rather than to the merits of the concept.

${ }^{61}$ See already ECJ judgment of 5 February 1963 in case 26/72, Van Gend \& Loos [ECR] 1963, p. 1.

${ }^{62}$ Not to speak of the broad variety of age and temperament.
} 
However, the larger the heterogeneity of the judges' bench is, the higher would be not only the likelihood of a divergence of views but even the risk of disagreement and permanent conflicts of opinion. And, as a matter of fact, as seen from the often very different backgrounds of the judges, this is not merely a theoretical question. Hence, it is very important to preserve as far as possible the serenity of the deliberations in order to allow for an open-minded discussion and for leaving aside mutual prejudice.

EU courts' chambers act by majority decisions. ${ }^{63}$ Even where more than superficial divergences have emerged, a judge who would not have succeeded in convincing the majority of the chamber would not retire from the deliberations like in a snail shell, but would continue to take part actively in the on-going discussion on the basis of the premise of a majority opinion he or she did not agree with ("stante concluso"), and contribute, with his or her best efforts, to render the final judgment's argumentation as consistent and convincing as possible. This exercise may be particularly difficult for a reporting judge who, although adhering to an adverse minority opinion, is expected to serve, with full loyalty, the majority opinion and not, like a pouting child, to throw away his or her duty to prepare (elaborate) a finalised judgment.

Yet, it is more than evident that, as soon as the publication of dissenting opinions were admitted, the dissenting judge, on the basis of his or her firm personal conviction, would leave the internal deliberation process and concentrate solely on the elaboration of a formal dissenting opinion. Likewise, on their side, the other members of the chamber would continue their internal deliberations, leaving deliberately the dissenter outside, since he or she would, anyhow, be free to present his or her own dissenting opinion. Consequently, the publication of dissenting opinions would dramatically impair the unique and unparalleled form of cooperation and cohesion which privileges and characterises the EU courts in comparison with many other international courts. ${ }^{64}$ For even if, at these other courts, there may be a spirit of collegiality, this could probably not be compared to the spirit of solidarity needed and present at EU courts, ${ }^{65}$ welding together the members of the judicial board and uniting their efforts in the common endeavour to serve the unity of EU law. ${ }^{66}$

\section{Conclusion}

Legal argumentation involves normally an evaluation process, and very often, at least prima facie, for a given legal problem more than one solution or way of solving it would appear to be equally reasonable and justifiable.

Therefore, in itself, from a merely intellectual point of view, unveiling, through dissenting opinions, the fact that in the course of the deliberations different positions have been taken by various members of a judicial panel would not be shocking.

\footnotetext{
${ }^{63}$ Accordingly, all EU judicial boards are staffed with an odd number of judges to avoid a tie.

${ }^{64}$ Following some recent publications, the possibility of expressing dissenting opinions did not lead to major problems in the different working frame of the European Court of Human Rights: see White/I. Boussiakou [7, 38], p. 37. See also Arnold [2], Rivière [30].

${ }^{65} \mathrm{See}$, in this same sense, also Sereni [32], at p. 844.

${ }^{66}$ Reminding of the motto of Emperor Francis-Joseph I for the multinational Austro-Hungarian empire: "Viribus unitis."
} 
It might also be an incentive, for the majority of the panel, to strengthen the reasoning of their judgment in order to let it appear convincing even by contrast to a published dissenting opinion and to possibly avoid getting stuck in a non-reflected and untinged mere repetition of case law formulas, maybe, without paying attention to the factual and legal specificities of the case.

Nevertheless, it would seem to me that EU law is still in a phase of consolidation which, given the manifold factors and tensions at stake, would let it seem advisable not to abandon, at least in the course of the next decades, the secrecy of deliberations in order to serve the EU courts' legitimacy with a view to stabilising the EU legal order.

This appreciation is confirmed by a look at the particular constraints of the EU courts' internal decision-making. But the on-going debate on a possible disclosure of dissenting opinions should be seen by EU courts as a very serious motive to pay due attention to the standard of reasoning in their judgments.

\section{References}

1. Arndt, K.: Nachlese zur Dissenting Opinion. In: Caemmerer, E.V., Mentschikoff, S., Zweigert, K. (eds.) Ius privatum gentium, Festschrift für Max Rheinstein zum 70. Geburtstag, Bd. I. Rechtsmethodik und internationals Recht. J.C.B. Mohr (Paul Siebeck), Tübingen (1969)

2. Arnold, N.-L.: The Legal Culture of the European Court of Human Rights. The Raoul Wallenberg Institute Human Rights Library, vol. 29. Martinus Nijhoff, Leiden (2007)

3. Beth, L.P.: The judicial committee of the privy council and the development of judicial review. Am. J. Com. Law 24 (1976)

4. De Savornin Lohman, O.: Preadvies. In: Handelingen 1973 der Nederlandse Juristen-Vereniging deel 1, eerste stuk. W.E.J. Tjeenk Willink, Zwolle (1973)

5. Drion, H.: Preadvies. In: Handelingen 1973 der Nederlandse Juristen-Vereniging deel 1, eerste stuk. W.E.J. Tjeenk Willink, Zwolle (1973)

6. Faller, H.J.: Beratungsgeheimnis, 'dissenting vote' und richterliche Unabhängigkeit. DVB1 p. 985 (1995)

7. Frowein, J.A., Peukert, W.: Europäische Menschenrechtskonvention, EMRK-Kommentar, 3rd edn. N.P. Engel Verlag, Kehl (2009)

8. Grabenwarter, C.: Die Bedeutung der "dissenting opinon" in der Praxis des Europäischen Gerichtshofs für Menschenrechte. JRP (1999)

9. Grabenwarter, C.: Europäische Menschenrechtskonvention, 2nd edn. Beck/Manz, München/Wien (2005)

10. Hakenberg, W., Stix-Hackl, C.: Handbuch zum Verfahren vor dem Europäischen Gerichtshof, 2nd edn. Verlag Österreich, Wien (2005)

11. Heyde, W.: Dissenting Opinions in der deutschen Verfassungsgerichtsbarkeit. Jahrbuch des öffentlichen Rechts, Neue Folge, Bd. 19

12. Hussain, I.: Dissenting and Separate Opinions at the World Court. Martinus Nijhoff, Dordrecht (1984)

13. Jackson: The Supreme Court in the American System of Government (1955)

14. Klinke, U.: Der Gerichtshof der Europäischen Gemeinschaften - Aufbau und Arbeitsweise. Nomos Verlagsgesellschaft, Baden-Baden (1989)

15. Knaub, G.: La procédure devant la Cour de Justice des Communautés Européennes. Rev. Trimest. Droit Eur. 3(1) (1967)

16. Laffranque, J.: Dissenting Opinion and Judicial Independence. Juridica International, vol. VIII (2003)

17. Laffranque, J.: Dissenting Opinion in the European Court of Justice-Estonia's Possible Contribution to the Democratisation of the European Union Judicial System. Juridica International, vol. IX (2004)

18. Lagrange, M.: La Cour de Justice de la Communauté. Bull. Assoc. Jurist. Eur. 13-14 (1963)

19. Lamprecht, R.: Fragwürdige Schweigepflicht - Plädoyer für ein Recht zur "Dissenting Opinion" bei den Obergerichten. ZRP (2010)

20. Lemonon, L.: La seconde Conférence de la Paix. Paris (1908) 
21. Louis, J.V., Vandersanden, G., Waelbroek, D., Waelbroek, M.: La Cour de justice-Les actes des institutions, Commentaire Megret, Le droit de la CEE, 2nd edn. Etudes européennes, Bruxelles (1993)

22. Machacek, R.: Die Einführung der "Dissenting Opinion" im internationalen Vergleich, Einführung des Minderheitenvotums am Verfassungsgerichtshof. JRP (1999)

23. Mayer, H.: Die Einführung der "dissenting opinion" am Verfassungsgerichtshof aus der Sicht der österreichischen Verfassungslehre, Einführung des Minderheitenvotums am Verfassungsgerichtshof. JRP (1999)

24. Noll, A.J.: Transparenz und Kontrolle im verfassungsgerichtlichen Verfahren - Zu einem gescheiterten Versuch, die dissenting opinion beim VfGH einzuführen (Entwurf einer Novelle des §26 VfGG 1953), AnwB1 (1993/4), and (1993/5)

25. Panizza, S.: L'Introduzione dell'Opinione Dissenziente nel Sistema di Giustizia Costituzionale. G. Giappichelli editore, Torino (1998)

26. Papier, H.P.: Die richterliche Unabhängigkeit und ihre Schranken. NJW (2001)

27. Peltzer, O.M.: Die Dissenting Opinion in der Schiedsgerichtsbarkeit. Peter Lang Europäischer Verlag der Wissenschaften, Frankfurt/Main (2000)

28. Philipp, C.: Das Judicial Committee of The Privy Council und seine Gerichtsbarkeit für das Commonwealth - Ursprung. Entwicklung und heutige Stellung, Kiel (1990)

29. Riese, O.: Erfahrungen aus der Praxis des Gerichtshofs der Europïschen Gemeinschaft für Kohle und Stahl. Deutsche Richterzeitung (1958)

30. Rivière, F.: Les opinions séparées des juges à la Cour européenne des Droits de l'homme. Bruylant, Bruxelles (2004)

31. Rupp, H.G.: Zur Frage der Dissenting Opinion. In: Bracher, K.D., Geiger, C., Dawson, Smend, W.R. (eds.) Die moderne Demokratie und ihr Recht (Modern Constitutionalism and Democracy), Festschrift für Gerhard Leibholz zum 65. Geburtstag, Bd. 2. Staats- und Verfassungsrecht. J.C.B. Mohr (Paul Siebeck), Tübingen (1966)

32. Sereni, A.P.: Les opinions individuelles et dissidentes des juges des tribunaux internationaux. Rev. Gén. Droit Int. Publ. troisième série-tome XXXV, vol. LXVIII, p. 830 (1964) (at p. 840fff)

33. Storme, M., Maresceau, M.: Europese Rechtspleging en Rechtspraak. Wetenschappelijke uitgeverij E. Stoy-Scientia P.V.B.A., Gent (1979)

34. Thomassen, W.: Het geheim van raadkamer en de dissenting opinion. NJB 12 (2006)

35. Tizzano: La Corte di giustizia delle Comunità europee I, Casa editrice dott. Eugenio Novene, Napoli (1967) sees in the secrecy of the deliberations not only a reflection of national practice, but also a means to reinforce the authority of the Court's judgments

36. Trócsányi/a. Horváth, L.: La pratique des opinions dissidentes en Hongrie-Les opinions individuelles en Hongrie: une institution. Cahiers du Conseil constitutionnel $n^{\circ} 8$ (Dossier: Débat sur les opinions dissidents)_-juillet (2000)

37. White, C.A.: Boussiakou, Separate opinions in the European Court of Human rights. Hum. Rights Law Rev. 9, 1 (2009)

38. Witenberg, J.C.J.: Desrioux: L'organisation Judiciaire-La Procédure et la Sentence Internationales, Traité pratique. Éd. Pedone, Paris (1937)

39. Zweigert, K.: Hauptreferat. In: Zehn Jahre Rechtsprechung des Gerichtshofs der Europäischen Gemeinschaften, Europäische Arbeitstagung, Köln, 24.-26.4.1963. Carl Heymanns Verlag, Köln (1965)

40. Brown, Kennedy: The Court of Justice of the European Communities, 5th edn. Sweet\&Maxwell, London (2000)

41. Lamprecht, R.: Richter contra Richter - Abweichende Meinungen und ihre Bedeutung für die Rechtskultur. Nomos, Baden-Baden (1992) 